\title{
PROMOTING WELL-BEING: THE CONTRIBUTION OF EMOTIONAL INTELLIGENCE \\ IN HR OF A COMPANY (THE CASE OF ALBANIA)
}

In Happiness And Contemporary Society : Conference Proceedings Volume (Lviv, March, 20-21, 2021). Lviv: SPOLOM, 2021. P. 224-237. https://doi.org/10.31108/7.2021.51

ISBN 978-966-919-697-2 


\author{
PLAKU Loida \\ MSc in Banking and Finance (Tirana, Albania)
}

\title{
PROMOTING WELL -BEING: THE CONTRIBUTION OF EMOTIONAL INTELLIGENCE IN HR OF A COMPANY (THE CASE OF ALBANIA)
}

The work environment is constantly changing. It is necessary to adapt effectively in order to have an increased productivity. Terms such as leadership, mindset, long-term goals, critical or analytical mind are the key factors that are deciding the fate of a certain company. In our country, it is mainly young people who are aware of the positive consequences of practicing emotional intelligence. But how easy is it to practice these qualities in a country like Albania? Recently, various trainings are being held for the development of individual performance, but does the Albanian society really know what it means to have an individual performance? One of the basic principles of Adlerian psychology is closely related to the principles of EQ: Thinking of the common good. How can this happen when everyone is supposed to think for themselves?

The paper is based on the interpretation of the main tests of Emotional Intelligence by comparing them with the data from a questionnaire that is addressed to 100 employees or people who have at least worked 1 time with contractual agreement. Main tests used are those based on Daniel Goleman's EQ Framework, specifically "360 degree" instrument.

Keywords: Emotional intelligence, HR practices, Leadership, Humanity, Happiness.

\section{Introduction}

Our emotions are so powerful, they can take over ability to think rationally. This is common within all of us a human-beings, but when it becomes a normal occurrence with an individual, they typically lack control over their emotions. In other words, they lack emotional intelligence. (Daniel Brain 2021) Emotional Intelligence (EI or EQ) was first introduced in 1990 by Peter Salovey and John Mayer and belongs to the beginning of Z generation. Also, there are proofs that this term is used before 1990 in some doctoral dissertation. Since that time, environment and a person's mindset have changed a lot and are constantly changing. So, it is very necessary to practice appropriate behaviors to adapt to this change. There are different approaches of EI related with leadership and HR practices. Numerous studies have given great weight to the emotional part leadership entails, since in a group of people it is the leader who has the greatest power to influence the emotions of others. Employees with a high EI scale are more likely to express their emotions in the most appropriate way and furthermore understanding the emotions of those they work with. Consequently, they enhance work relationships and performance. In "What makes a leader?" Goleman introduces by his research that truly effective leaders are characterized by a high degree of EI. Jim Goodnight, the CEO of one of the most powerful companies in the market, SAS, states "Treat employees like they make a difference and they will." Cultivating a human conscience leads to the proper cultivation of a nation's potential, and I strongly believe that this is the only impetus for all-round 
development, which would lead to nationwide happiness. It is often said that it does not cost a thing to be polite. On the contrary, it costs a lot. It costs experience, humility, empathy, maturity, sacrifice, ingenuity, emotion. Let's start helping the world to be a better place, by helping the person next to us. Solving problems should start with humanity and all of this requires emotional intelligence. It is becoming more and more necessary to establish faithful long-term relationships every day, both at work and in daily life. To have these relationships we must not rely on manipulation, but on the truth.

Thinking For The Good Of Community, Emotional Intelligence And Leadership

Humanism is born with the creation of consciousness, because with the birth of consciousness also reason arises. (Alfred Adler) Generally, being human means being a "good person", but in reality, it is not that simple. (Simon Sinek) Being human means living life thinking about the well-being of the community. (Fumitake Koga and Ichiro Kishimi, 2013) To live thinking about the well-being of the community means to live thinking that you are not alone, but every action of yours has consequences for others and vice versa. In other words, we cannot avoid interpersonal relationships. You will never know the real joy of living until you come into a full understanding of the Principle of Service. (Napoleon Hill) Almost every person or organization needs to encourage others to take action for one reason or another. Leaders belong to that very special group of managers, who do something very special. They inspire us. Those who have this ability can give people a feeling which has nothing to do with any external stimulus, or potential benefit. Those who truly lead have the ability to create a group of followers, who do not take action because they were influenced but because they were inspired. The concept of the Golden Circle by Simon Sinek is based on Emotional Intelligence. The Golden Circle, based on the natural principles of biology, obeys the need for balance. When there is no reason why, imbalance is produced and thus manipulations come to life. And when that happens, uncertainty grows for buyers, volatility for sellers, and stress for everyone. Starting with why is just the beginning. There is a lot of work to be done before a person or organization gains the right or ability to inspire. For the Golden Circle to function, each part must be in balance and in the right order. Everything starts with clarity. When it is understood what we should do, the question is how should it be done? By "HOW, Simon Sinek means the values, the principles, the ethics and the morals that guide us to give our life a purpose. And then he adds that everything we say and do must be a proof of what we believe.

\section{Truthful Living Requires High Emotional Intelligence}

Words change lives and this is one of the major contributions of a good cultivation of EQ skills can do. It is all related with psychology. Psychology is nothing more nor less than a thorough understanding of the manner in which the human mind works. To understand psychology is to understand humanity. To make practical application of psychology is to direct and control the human mind and particularly your mind. The principles through which psychology may be used are comparatively simple and all it requires is concentration. In order to have a truthful living it is a must for e person to develop Emotional Intelligence qualities such as self-confidence, courage, faith, humility, a good working knowledge of "self". People with high EQ know that everything starts with the thinking. And so, if you become a great employee, it will because you have first willed to become great. If you fail to become a great employee, it 
will be because your will power was of the half-hearted brand. (Napoleon Hill) When defeat overtakes a man or a woman, the easiest and the most logical thing to do is to quit. That's exactly what the majority of employees do. Most employees or managers are not willing to do the hard work that it takes to make success easy. (Napoleon Hill)

\section{Daniel Goleman model of Emotional Intelligence}

Daniel Goleman's model of emotional intelligence has three levels: brain circuitry, domains that emerge from circuits' activity and competencies that depend on each EI domain. First there are the neutral circuits at play, particularly the dynamic between the prefrontal cortex, which is the brain's executive center, and the emotional circuitry, especially the amygdala, which triggers our upsets on the one hand or gets us motivated on the other. The self-awareness and self-management domains of EI depend on this brain activity. Then, separately, there are a suite of circuits in the forebrain that serve social functions like empathy, attunement and synchrony. Empathy and social skills largely emerge from the activity of these social brain circuits. A view of human nature that constantly ignores the power of emotions is sadly shortsighted. (Daniel Goleman) The humanity has gone too far in emphasizing the value of what IQ measures in life. Intelligence can come to nothing when the emotions are not properly perceived and understood. The one with a high EI has the tendency to win the Aristotle challenge which states: "Anyone can become angry-that is easy. But to be angry with the right person, to the right degree, at the right time, for the right purpose, and in the right waythat is not easy." (Aristotle, The Art of Rhetoric)

\section{Methodology}

I addressed a questionnaire to 100 employees based on the Daniel Boheman' EI Framework including "360 degree" instrument with Daniel Goleman's ESCI. The main hypotheses raised are whether Albanian employees show interest in the practices of competencies that are characterized by emotional intelligence. I have analyzed qualitative research from a psychological, philosophical, economic point of view based also on the MSCEIT test (2002) and The Bar-On Emotional Quotient Inventory.

\section{Results and discussions}

They are mostly young people, those belonging to Generations $\mathrm{Z}$ and $\mathrm{Y}$ who know about the practices of emotional intelligence and the importance they have in society. Generation X although has no information, wants to learn more and is interested in getting involved in EI disciplines. In terms of happiness, no one wrote about being happy or optimistic. To me, one of the great purposes of life is to be happy all the time and to make others happy, because when you are happy you are in peace and when you are in peace you can be productive. To continue with the statistics, most of the responders think that their boss does not practice EI skills. This shows again a factor why the employee happiness curve in Albanian companies is not positively sloping. One possible reason why most CEOs do not practice Emotional Intelligence competencies may be the fact that most of them are adults and do not have the same approach to this ideology as young people. This is shown even from questionnaire statistics. 58 out of 100 respondents do not think that there is an Albanian Company that practice good Human Capital Trainings. Based on Bar-On' fourth zone in reality testing, I would say that Albanian youth hopes for new recruitment practices from current Human Resources. "Selfcontrol" competency is dominated by $43 \%$ and the "optimism" competency is dominated 
by only $12 \%$. This fact confirms once again what I said above that respondents tend to have low inclination towards happiness. Most of them are ware if individual performance, but are not optimistic about external factors. This means that they are not working at peace and they are constantly controlling their emotions. Another very positive aspect is that the most of them accept diversity on their workplace and they affirm they can learn from them in order to increase their performance. (please refer to the table section)

Figures and tables

Table1. Summary of the responders EI test (in\%)

\begin{tabular}{|c|c|c|c|c|c|}
\hline Situations & $\begin{array}{l}1(\text { not at } \\
\text { all) }\end{array}$ & 2(rarely) & 3 (sometimes) & 4 (often) & $\begin{array}{l}5 \text { (Very } \\
\text { often) }\end{array}$ \\
\hline $\begin{array}{l}\text { 1) In order to be productive in } \\
\text { teamwork I } \text { should consider } \\
\text { improving } \\
\text { management. }\end{array}$ & $3 \%$ & $12 \%$ & $34 \%$ & $27 \%$ & $24 \%$ \\
\hline $\begin{array}{l}\text { 2) I always know which emotions I } \\
\text { am feeling and why. }\end{array}$ & $4 \%$ & $12 \%$ & $23 \%$ & $39 \%$ & $22 \%$ \\
\hline $\begin{array}{l}\text { 3) I recognize how my feelings } \\
\text { affect my performance. }\end{array}$ & $4 \%$ & $9 \%$ & $40 \%$ & $24 \%$ & $23 \%$ \\
\hline $\begin{array}{l}\text { 4) I am aware of my strengths } \\
\text { and weaknesses. }\end{array}$ & $3 \%$ & $10 \%$ & $42 \%$ & $19 \%$ & $26 \%$ \\
\hline $\begin{array}{l}\text { 5) I am open to candid feedback, } \\
\text { new perspectives, continuous } \\
\text { learning, and self-development. }\end{array}$ & $3 \%$ & $9 \%$ & $21 \%$ & $39 \%$ & $28 \%$ \\
\hline $\begin{array}{l}\text { 6) I present myself with self- } \\
\text { assurance; I have "presence" }\end{array}$ & $5 \%$ & $11 \%$ & $24 \%$ & $17 \%$ & $43 \%$ \\
\hline $\begin{array}{l}\text { 7)I can voice views that are } \\
\text { unpopular and go out on a limb } \\
\text { for what is right. }\end{array}$ & $4 \%$ & $10 \%$ & $27 \%$ & $42 \%$ & $17 \%$ \\
\hline $\begin{array}{l}\text { 8) I think clearly and stay focused } \\
\text { under pressure }\end{array}$ & $4 \%$ & $10 \%$ & $42 \%$ & $22 \%$ & $22 \%$ \\
\hline $\begin{array}{l}\text { 9) I build trust by being reliable } \\
\text { and authentic. }\end{array}$ & $3 \%$ & $8 \%$ & $34 \%$ & $32 \%$ & $23 \%$ \\
\hline $\begin{array}{l}\text { 10) I am organized and careful in } \\
\text { my work. }\end{array}$ & $3 \%$ & $7 \%$ & $26 \%$ & $34 \%$ & $30 \%$ \\
\hline $\begin{array}{l}\text { 11) I am flexible in how I see } \\
\text { events. }\end{array}$ & $3 \%$ & $10 \%$ & $22 \%$ & $41 \%$ & $24 \%$ \\
\hline $\begin{array}{l}\text { 12) I generate new ideas and take } \\
\text { fresh perspectives and risks in my } \\
\text { thinking }\end{array}$ & $5 \%$ & $9 \%$ & $41 \%$ & $21 \%$ & $24 \%$ \\
\hline $\begin{array}{l}\text { 13)I am results-oriented, with a } \\
\text { high drive to meet objectives and } \\
\text { standards }\end{array}$ & $5 \%$ & $7 \%$ & $38 \%$ & $27 \%$ & $23 \%$ \\
\hline $\begin{array}{l}\text { 14) I continuously learn in order } \\
\text { to improve my performance. }\end{array}$ & $5 \%$ & $10 \%$ & $38 \%$ & $20 \%$ & $27 \%$ \\
\hline $\begin{array}{l}\text { 15) I am willing to make personal } \\
\text { or group sacrifices to meet a } \\
\text { larger organizational goal. }\end{array}$ & $25 \%$ & $12 \%$ & $26 \%$ & $25 \%$ & $12 \%$ \\
\hline $\begin{array}{l}\text { 16) I am always ready to seize } \\
\text { opportunities. }\end{array}$ & $4 \%$ & $9 \%$ & $18 \%$ & $46 \%$ & $23 \%$ \\
\hline $\begin{array}{l}\text { 17) I see setbacks as due to } \\
\text { manageable circumstance rather } \\
\text { than a personal flaw }\end{array}$ & $6 \%$ & $10 \%$ & $46 \%$ & $22 \%$ & $16 \%$ \\
\hline $\begin{array}{l}\text { 18) I show sensitivity and } \\
\text { understand others' perspectives. }\end{array}$ & $4 \%$ & $8 \%$ & $17 \%$ & $42 \%$ & $29 \%$ \\
\hline
\end{tabular}




\begin{tabular}{|c|c|c|c|c|c|}
\hline $\begin{array}{l}\text { 19) I understand customers' needs } \\
\text { and match them to services or } \\
\text { products. }\end{array}$ & $4 \%$ & $9 \%$ & $41 \%$ & $21 \%$ & $25 \%$ \\
\hline $\begin{array}{l}20 \text { I I grasp a customer's } \\
\text { perspective, acting as a trusted } \\
\text { advisor }\end{array}$ & $5 \%$ & $12 \%$ & $17 \%$ & $24 \%$ & $42 \%$ \\
\hline 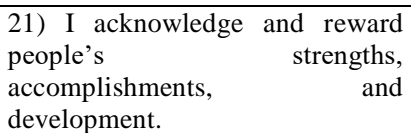 & $3 \%$ & $8 \%$ & $22 \%$ & $27 \%$ & $40 \%$ \\
\hline $\begin{array}{l}\text { 22) I respect and relate well to } \\
\text { people from varied backgrounds. }\end{array}$ & $3 \%$ & $6 \%$ & $17 \%$ & $50 \%$ & $24 \%$ \\
\hline $\begin{array}{l}\text { 23) I try to understand diverse } \\
\text { worldviews and be sensitive to } \\
\text { group differences. }\end{array}$ & $3 \%$ & $9 \%$ & $16 \%$ & $46 \%$ & $26 \%$ \\
\hline $\begin{array}{l}\text { 24) I have a good understanding } \\
\text { of the forces that shape the views } \\
\text { and actions of clients, customers, } \\
\text { or competitors. }\end{array}$ & $4 \%$ & $8 \%$ & $22 \%$ & $45 \%$ & $21 \%$ \\
\hline $\begin{array}{l}\text { 25) I am able to use complex } \\
\text { strategies like indirect influence } \\
\text { to build consensus and support. }\end{array}$ & $4 \%$ & $11 \%$ & $20 \%$ & $42 \%$ & $23 \%$ \\
\hline $\begin{array}{l}\text { 26) I deal with difficult issues } \\
\text { straightforwardly }\end{array}$ & $6 \%$ & $13 \%$ & $37 \%$ & $21 \%$ & $23 \%$ \\
\hline 27) I lead by example. & $3 \%$ & $8 \%$ & $22 \%$ & $44 \%$ & $23 \%$ \\
\hline $\begin{array}{l}\text { 28) I recognize the need for } \\
\text { change and remove barriers to it. }\end{array}$ & $3 \%$ & $10 \%$ & $36 \%$ & $30 \%$ & $21 \%$ \\
\hline $\begin{array}{l}\text { 29) I model the change expected } \\
\text { of others. }\end{array}$ & $3 \%$ & $11 \%$ & $35 \%$ & $33 \%$ & $18 \%$ \\
\hline $\begin{array}{l}\text { 30) I encourage debate and open } \\
\text { discussion }\end{array}$ & $4 \%$ & $10 \%$ & $18 \%$ & $50 \%$ & $18 \%$ \\
\hline $\begin{array}{l}\text { 31) I orchestrate win-win } \\
\text { solutions. }\end{array}$ & $3 \%$ & $12 \%$ & $24 \%$ & $41 \%$ & $20 \%$ \\
\hline $\begin{array}{l}\text { 32) I seek out relationships that } \\
\text { are mutually beneficial. }\end{array}$ & $4 \%$ & $11 \%$ & $16 \%$ & $48 \%$ & $21 \%$ \\
\hline $\begin{array}{l}\text { 33) I balance a focus on task with } \\
\text { attention to relationships }\end{array}$ & $3 \%$ & $10 \%$ & $22 \%$ & $46 \%$ & $19 \%$ \\
\hline $\begin{array}{l}\text { 34) I model team qualities like } \\
\text { respect, helpfulness, } \\
\text { cooperation. }\end{array}$ & $4 \%$ & $7 \%$ & $16 \%$ & $49 \%$ & $24 \%$ \\
\hline $\begin{array}{l}\text { 35) People have told me that I'm a } \\
\text { good listener. }\end{array}$ & $4 \%$ & $7 \%$ & $20 \%$ & $42 \%$ & $27 \%$ \\
\hline
\end{tabular}

Source: My own research

\section{Conclusion}

In this article I examined how Emotional Intelligence can be acquired, not by analyzing it directly, but by analyzing it in details by grasping its most hidden competencies. Often, we analyze the phenomenon in a directly way in order to give an answer, when in fact we have to analyze the causes why it happens. It was concluded that in Albania, generation $\mathrm{Z}$ wants to know more about Emotional Intelligence and want to practice its special disciplines. This is something very positive for our country, as mentality and leadership are what empowers a nation. 


\section{Figures and tables}

1.How old are you?

100 responses

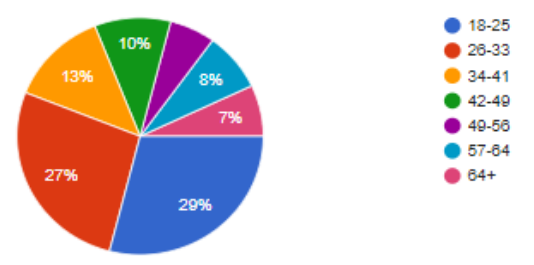

2.What is your gender?

100 responses

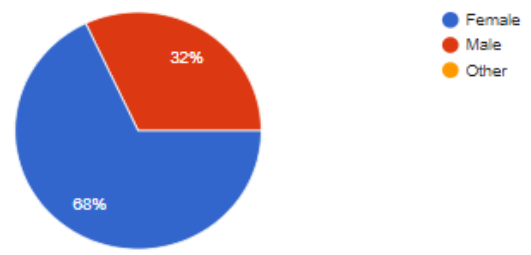

Figure 1. Two first questions in the first part of the survey

Source: Google Forms, Drive: 1plaku20@epoka.edu.al 3.Where do you live ?

100 responses

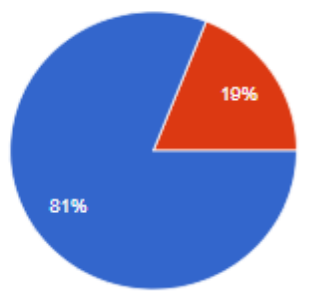

Tiranë

Other city in Albania

4.What did you graduate in?

100 responses

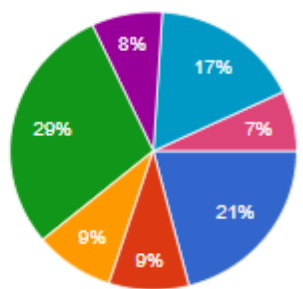

Faculty of Economics

Faculty of Engineering

- Faculty of Medicine

- Faculty of Law

- Faculty of Arts

Other

I have not graduated yet

Figure $2.3^{\text {d }}$ and $4^{\text {th }}$ questions of the first part of the survey

Source: Google Forms, Drive: 1plaku20@epoka.edu.al 
5.Have you ever worked one time with contractual agreement or are you actually working? (Please select No if you have never worked before)

100 responses

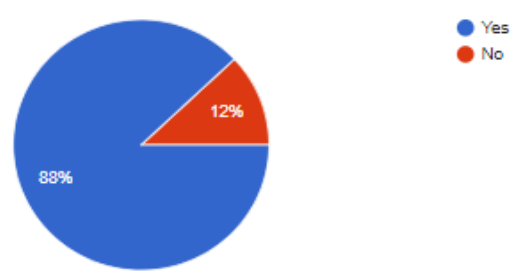

6.Are you familiar with "Emotional Intelligence" term ?

100 responses

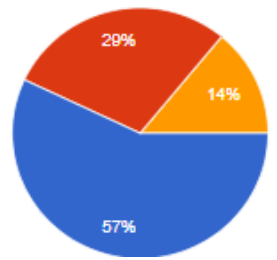

\section{Yes}

Maybe

Figure 3. $5^{\text {th }}$ and $6^{\text {th }}$ questions of the first part of the survey

Source: Google Forms, Drive: lplaku20@epoka.edu.al

1) Emotional Intelligence is the skill of life.

100 responses

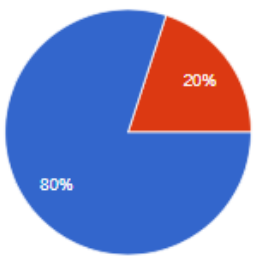

- Agree

2) Are you interested in learning more about Emotional Intelligence?

100 responses

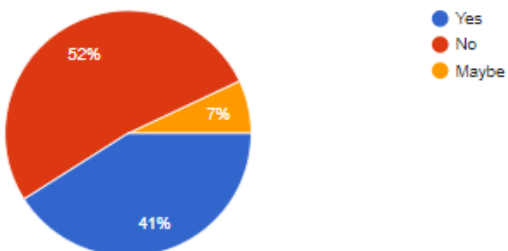

Figure 4. Two first questions of the last part of the survey.

Source: Google Forms, Drive: 1plaku20@epoka.edu.al 
3) Have you ever tried to move out from your comfort zone?

100 responses

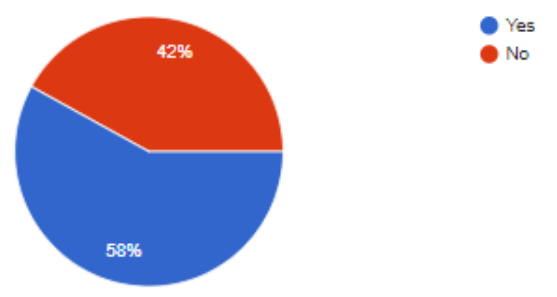

4) Which zone you think requires a higher Emotional Intelligence scale?

100 responses

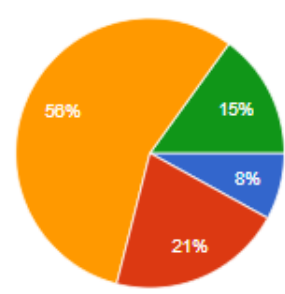

$$
\begin{aligned}
& \text { - Comfort Zone } \\
& \text { Fear Zone } \\
& \text { Learning Zone } \\
& \text { - Growth Zone }
\end{aligned}
$$

Figure 5. $3^{\mathrm{d}}$ and $4^{\text {th }}$ questions of the first part of the survey

Source: Google Forms, Drive: lplaku20@epoka.edu.al 5) Please write it down the first " 3 skills group" that comes us to your mind when you think about Emotional Intelligence.

100 responses

Teamwork costumer service colleague relationship

Ambitious, good listener, honest

Understanding

Patience

Empathy

Good listener

Be flexible

Keep your team informed

Motivation/ mindset/ growth

Strength, patience, maturity

understanding, listening and share knowledge

Figure 6. $5^{\text {th }}$ question of the last part of the survey

Source: Google Forms, Drive: 1plaku20@epoka.edu.al 
6) Now that you know more about EQ, do you think your boss practices Emotional Intelligence skills?

100 responses

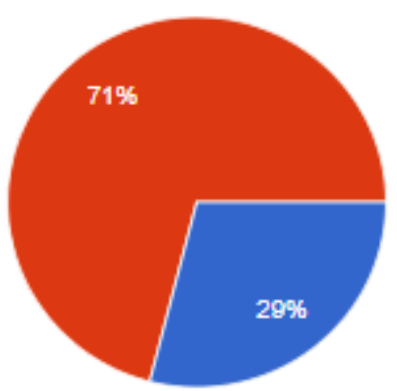

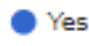

No

Figure7. $6^{\text {th }}$ question of the last part of the survey

Source: Google Forms, Drive: lplaku20@epoka.edu.al

7) Please write it down at least one Albanian company you think practices good Human Capital Trainings?

91 responses

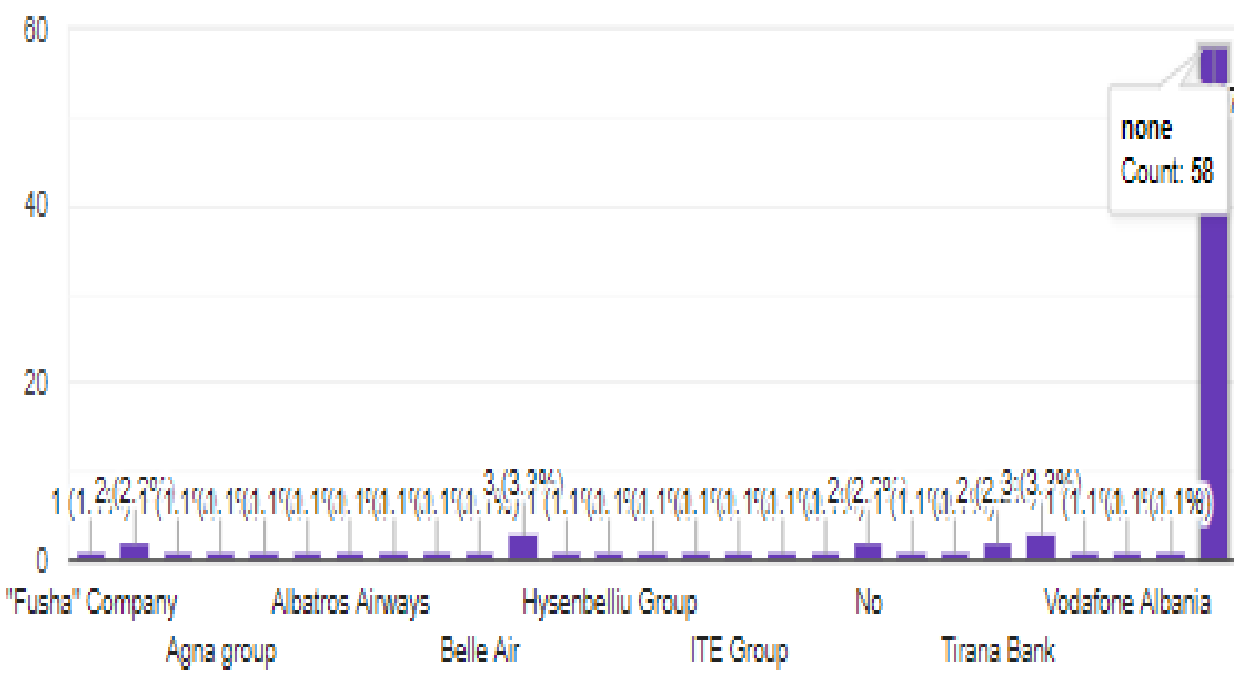

Figure8. $7^{\text {th }}$ question of the last part of the survey

Source: Google Forms, Drive: 1plaku20@epoka.edu.al 
Table1. Summary of the responders EI test (in\%)

\begin{tabular}{|c|c|c|c|c|c|}
\hline Situations & $\begin{array}{l}1 \text { (not at } \\
\text { all) }\end{array}$ & 2 (rarely) & 3 (sometimes) & 4 (often) & $\begin{array}{l}5 \text { (Very } \\
\text { often) }\end{array}$ \\
\hline $\begin{array}{l}\text { 1) In order to be productive in } \\
\text { teamwork I } \\
\text { improving }\end{array}$ & $3 \%$ & $12 \%$ & $34 \%$ & $27 \%$ & $24 \%$ \\
\hline $\begin{array}{l}\text { 2) I always know which emotions I } \\
\text { am feeling and why. }\end{array}$ & $4 \%$ & $12 \%$ & $23 \%$ & $39 \%$ & $22 \%$ \\
\hline $\begin{array}{l}\text { 3) I recognize how my feelings } \\
\text { affect my performance. }\end{array}$ & $4 \%$ & $9 \%$ & $40 \%$ & $24 \%$ & $23 \%$ \\
\hline $\begin{array}{l}\text { 4) I am aware of my strengths } \\
\text { and weaknesses. }\end{array}$ & $3 \%$ & $10 \%$ & $42 \%$ & $19 \%$ & $26 \%$ \\
\hline $\begin{array}{l}\text { 5) I am open to candid feedback, } \\
\text { new perspectives, continuous } \\
\text { learning, and self-development. }\end{array}$ & $3 \%$ & $9 \%$ & $21 \%$ & $39 \%$ & $28 \%$ \\
\hline $\begin{array}{l}\text { 6) I present myself with self- } \\
\text { assurance; I have "presence" }\end{array}$ & $5 \%$ & $11 \%$ & $24 \%$ & $17 \%$ & $43 \%$ \\
\hline $\begin{array}{l}\text { 7)I can voice views that are } \\
\text { unpopular and go out on a limb } \\
\text { for what is right. }\end{array}$ & $4 \%$ & $10 \%$ & $27 \%$ & $42 \%$ & $17 \%$ \\
\hline $\begin{array}{l}\text { 8) I think clearly and stay focused } \\
\text { under pressure }\end{array}$ & $4 \%$ & $10 \%$ & $42 \%$ & $22 \%$ & $22 \%$ \\
\hline $\begin{array}{l}\text { 9) I build trust by being reliable } \\
\text { and authentic. }\end{array}$ & $3 \%$ & $8 \%$ & $34 \%$ & $32 \%$ & $23 \%$ \\
\hline $\begin{array}{l}\text { 10) I am organized and careful in } \\
\text { my work. }\end{array}$ & $3 \%$ & $7 \%$ & $26 \%$ & $34 \%$ & $30 \%$ \\
\hline $\begin{array}{l}\text { 11) I am flexible in how I see } \\
\text { events. }\end{array}$ & $3 \%$ & $10 \%$ & $22 \%$ & $41 \%$ & $24 \%$ \\
\hline $\begin{array}{l}\text { 12) I generate new ideas and take } \\
\text { fresh perspectives and risks in my } \\
\text { thinking }\end{array}$ & $5 \%$ & $9 \%$ & $41 \%$ & $21 \%$ & $24 \%$ \\
\hline $\begin{array}{l}\text { 13)I am results-oriented, with a } \\
\text { high drive to meet objectives and } \\
\text { standards }\end{array}$ & $5 \%$ & $7 \%$ & $38 \%$ & $27 \%$ & $23 \%$ \\
\hline $\begin{array}{l}\text { 14) I continuously learn in order } \\
\text { to improve my performance. }\end{array}$ & $5 \%$ & $10 \%$ & $38 \%$ & $20 \%$ & $27 \%$ \\
\hline $\begin{array}{l}\text { 15) I am willing to make personal } \\
\text { or group sacrifices to meet a } \\
\text { larger organizational goal. }\end{array}$ & $25 \%$ & $12 \%$ & $26 \%$ & $25 \%$ & $12 \%$ \\
\hline $\begin{array}{l}\text { 16) I am always ready to seize } \\
\text { opportunities. }\end{array}$ & $4 \%$ & $9 \%$ & $18 \%$ & $46 \%$ & $23 \%$ \\
\hline $\begin{array}{l}\text { 17) I see setbacks as due to } \\
\text { manageable circumstance rather } \\
\text { than a personal flaw }\end{array}$ & $6 \%$ & $10 \%$ & $46 \%$ & $22 \%$ & $16 \%$ \\
\hline $\begin{array}{l}\text { 18) I show sensitivity and } \\
\text { understand others' perspectives. }\end{array}$ & $4 \%$ & $8 \%$ & $17 \%$ & $42 \%$ & $29 \%$ \\
\hline $\begin{array}{l}\text { 19) I understand customers' needs } \\
\text { and match them to services or } \\
\text { products. }\end{array}$ & $4 \%$ & $9 \%$ & $41 \%$ & $21 \%$ & $25 \%$ \\
\hline $\begin{array}{l}\text { 20) I grasp a customer's } \\
\text { perspective, acting as a trusted } \\
\text { advisor }\end{array}$ & $5 \%$ & $12 \%$ & $17 \%$ & $24 \%$ & $42 \%$ \\
\hline $\begin{array}{lr}21 \text { I I acknowledge } & \text { and reward } \\
\text { people's } & \text { strengths, } \\
\text { accomplishments, } & \text { and } \\
\text { development. } & \end{array}$ & $3 \%$ & $8 \%$ & $22 \%$ & $27 \%$ & $40 \%$ \\
\hline $\begin{array}{l}\text { 22) I respect and relate well to } \\
\text { people from varied backgrounds. }\end{array}$ & $3 \%$ & $6 \%$ & $17 \%$ & $50 \%$ & $24 \%$ \\
\hline
\end{tabular}




\begin{tabular}{|c|c|c|c|c|c|}
\hline $\begin{array}{l}\text { 23) I try to understand diverse } \\
\text { worldviews and be sensitive to } \\
\text { group differences. }\end{array}$ & $3 \%$ & $9 \%$ & $16 \%$ & $46 \%$ & $26 \%$ \\
\hline $\begin{array}{l}\text { 24) I have a good understanding } \\
\text { of the forces that shape the views } \\
\text { and actions of clients, customers, } \\
\text { or competitors. }\end{array}$ & $4 \%$ & $8 \%$ & $22 \%$ & $45 \%$ & $21 \%$ \\
\hline $\begin{array}{l}\text { 25) I am able to use complex } \\
\text { strategies like indirect influence } \\
\text { to build consensus and support. }\end{array}$ & $4 \%$ & $11 \%$ & $20 \%$ & $42 \%$ & $23 \%$ \\
\hline $\begin{array}{l}\text { 26) I deal with difficult issues } \\
\text { straightforwardly }\end{array}$ & $6 \%$ & $13 \%$ & $37 \%$ & $21 \%$ & $23 \%$ \\
\hline 27) I lead by example. & $3 \%$ & $8 \%$ & $22 \%$ & $44 \%$ & $23 \%$ \\
\hline $\begin{array}{l}\text { 28) I recognize the need for } \\
\text { change and remove barriers to it. }\end{array}$ & $3 \%$ & $10 \%$ & $36 \%$ & $30 \%$ & $21 \%$ \\
\hline $\begin{array}{l}\text { 29) I model the change expected } \\
\text { of others. }\end{array}$ & $3 \%$ & $11 \%$ & $35 \%$ & $33 \%$ & $18 \%$ \\
\hline $\begin{array}{l}\text { 30) I encourage debate and open } \\
\text { discussion }\end{array}$ & $4 \%$ & $10 \%$ & $18 \%$ & $50 \%$ & $18 \%$ \\
\hline $\begin{array}{l}\text { 31) I } \\
\text { solutions. }\end{array}$ & $3 \%$ & $12 \%$ & $24 \%$ & $41 \%$ & $20 \%$ \\
\hline $\begin{array}{l}\text { 32) I seek out relationships that } \\
\text { are mutually beneficial. }\end{array}$ & $4 \%$ & $11 \%$ & $16 \%$ & $48 \%$ & $21 \%$ \\
\hline $\begin{array}{l}\text { 33) I balance a focus on task with } \\
\text { attention to relationships }\end{array}$ & $3 \%$ & $10 \%$ & $22 \%$ & $46 \%$ & $19 \%$ \\
\hline $\begin{array}{l}\text { 34) I model team qualities like } \\
\text { respect, helpfulness, and } \\
\text { cooperation. }\end{array}$ & $4 \%$ & $7 \%$ & $16 \%$ & $49 \%$ & $24 \%$ \\
\hline $\begin{array}{l}\text { 35) People have told me that I'm a } \\
\text { good listener. }\end{array}$ & $4 \%$ & $7 \%$ & $20 \%$ & $42 \%$ & $27 \%$ \\
\hline
\end{tabular}

Table2. Summary of the responders based on competencies (in\%)

\begin{tabular}{|l|l|l|l|l|l|}
\hline \multicolumn{1}{|c|}{ Competencies } & \multicolumn{1}{c|}{1} & \multicolumn{1}{c|}{2} & \multicolumn{1}{c|}{3} & \multicolumn{1}{c|}{5} \\
\hline self-control & $5 \%$ & $11 \%$ & $24 \%$ & $17 \%$ & $43 \%$ \\
\hline leveraging diversity & $5 \%$ & $12 \%$ & $17 \%$ & $24 \%$ & $42 \%$ \\
\hline political awareness & $3 \%$ & $8 \%$ & $22 \%$ & $27 \%$ & $40 \%$ \\
\hline innovativeness & $3 \%$ & $7 \%$ & $26 \%$ & $34 \%$ & $30 \%$ \\
\hline service orientation & $4 \%$ & $8 \%$ & $17 \%$ & $42 \%$ & $29 \%$ \\
\hline self-regulation & $3 \%$ & $9 \%$ & $21 \%$ & $39 \%$ & $28 \%$ \\
\hline initiative & $5 \%$ & $10 \%$ & $38 \%$ & $20 \%$ & $27 \%$ \\
\hline concentration & $4 \%$ & $7 \%$ & $20 \%$ & $42 \%$ & $27 \%$ \\
\hline self-confidence & $3 \%$ & $10 \%$ & $42 \%$ & $19 \%$ & $26 \%$ \\
\hline influence & $3 \%$ & $9 \%$ & $16 \%$ & $46 \%$ & $26 \%$ \\
\hline developing others & $4 \%$ & $9 \%$ & $41 \%$ & $21 \%$ & $25 \%$ \\
\hline self-awareness & $3 \%$ & $12 \%$ & $34 \%$ & $27 \%$ & $24 \%$ \\
\hline
\end{tabular}




\begin{tabular}{|c|c|c|c|c|c|}
\hline self-motivation & $3 \%$ & $10 \%$ & $22 \%$ & $41 \%$ & $24 \%$ \\
\hline achievement drive & $5 \%$ & $9 \%$ & $41 \%$ & $21 \%$ & $24 \%$ \\
\hline social skills & $3 \%$ & $6 \%$ & $17 \%$ & $50 \%$ & $24 \%$ \\
\hline $\begin{array}{l}\text { social to personal } \\
\text { competencies }\end{array}$ & $4 \%$ & $7 \%$ & $16 \%$ & $49 \%$ & $24 \%$ \\
\hline $\begin{array}{l}\text { accurate self- } \\
\text { assessment }\end{array}$ & $4 \%$ & $9 \%$ & $40 \%$ & $24 \%$ & $23 \%$ \\
\hline adaptability & $3 \%$ & $8 \%$ & $34 \%$ & $32 \%$ & $23 \%$ \\
\hline commitment & $5 \%$ & $7 \%$ & $38 \%$ & $27 \%$ & $23 \%$ \\
\hline social awareness & $4 \%$ & $9 \%$ & $18 \%$ & $46 \%$ & $23 \%$ \\
\hline leadership & $4 \%$ & $11 \%$ & $20 \%$ & $42 \%$ & $23 \%$ \\
\hline change catalyst & $6 \%$ & $13 \%$ & $37 \%$ & $21 \%$ & $23 \%$ \\
\hline conflict management & $3 \%$ & $8 \%$ & $22 \%$ & $44 \%$ & $23 \%$ \\
\hline emotional awareness & $4 \%$ & $12 \%$ & $23 \%$ & $39 \%$ & $22 \%$ \\
\hline conscientiousness & $4 \%$ & $10 \%$ & $42 \%$ & $22 \%$ & $22 \%$ \\
\hline communication & $4 \%$ & $8 \%$ & $22 \%$ & $45 \%$ & $21 \%$ \\
\hline building bonds & $3 \%$ & $10 \%$ & $36 \%$ & $30 \%$ & $21 \%$ \\
\hline reliability & $4 \%$ & $11 \%$ & $16 \%$ & $48 \%$ & $21 \%$ \\
\hline team capabilities & $3 \%$ & $12 \%$ & $24 \%$ & $41 \%$ & $20 \%$ \\
\hline $\begin{array}{l}\text { personal to social } \\
\text { competencies }\end{array}$ & $3 \%$ & $10 \%$ & $22 \%$ & $46 \%$ & $19 \%$ \\
\hline collaboration & $3 \%$ & $11 \%$ & $35 \%$ & $33 \%$ & $18 \%$ \\
\hline cooperation & $4 \%$ & $10 \%$ & $18 \%$ & $50 \%$ & $18 \%$ \\
\hline trustworthiness & $4 \%$ & $10 \%$ & $27 \%$ & $42 \%$ & $17 \%$ \\
\hline empathy & $6 \%$ & $10 \%$ & $46 \%$ & $22 \%$ & $16 \%$ \\
\hline optimism & $25 \%$ & $12 \%$ & $26 \%$ & $25 \%$ & $12 \%$ \\
\hline
\end{tabular}




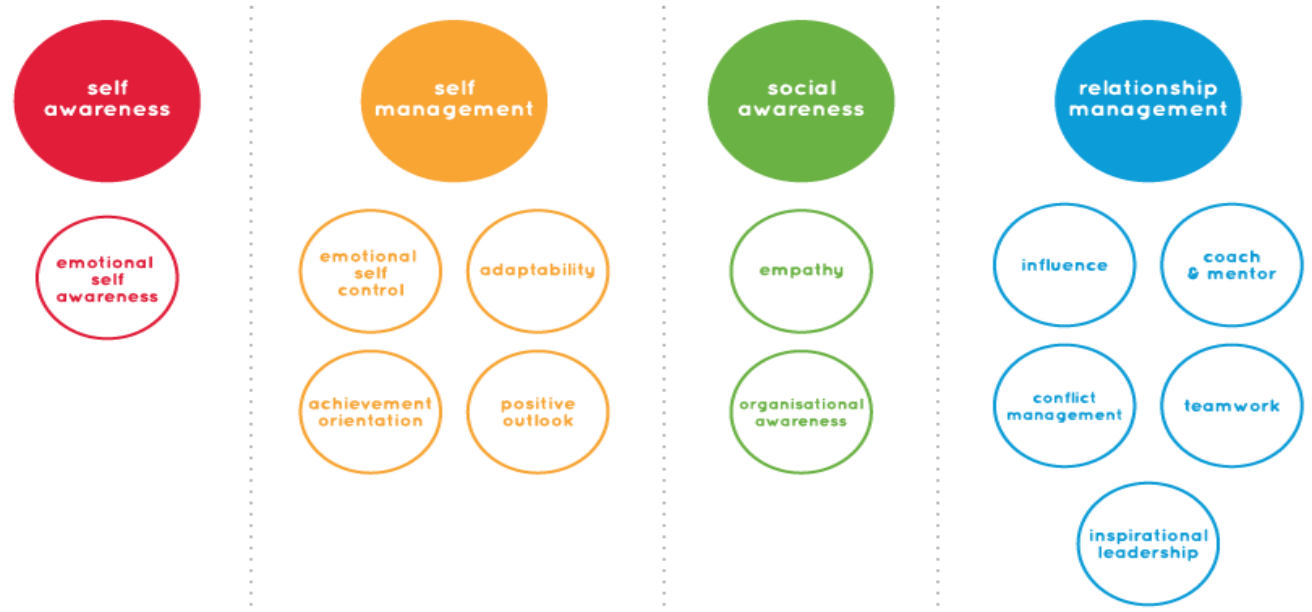

Figure 9. Daniel Goleman's ESCI (Emotional and Social Competency Inventory)

Source: https://jodierogers.com/

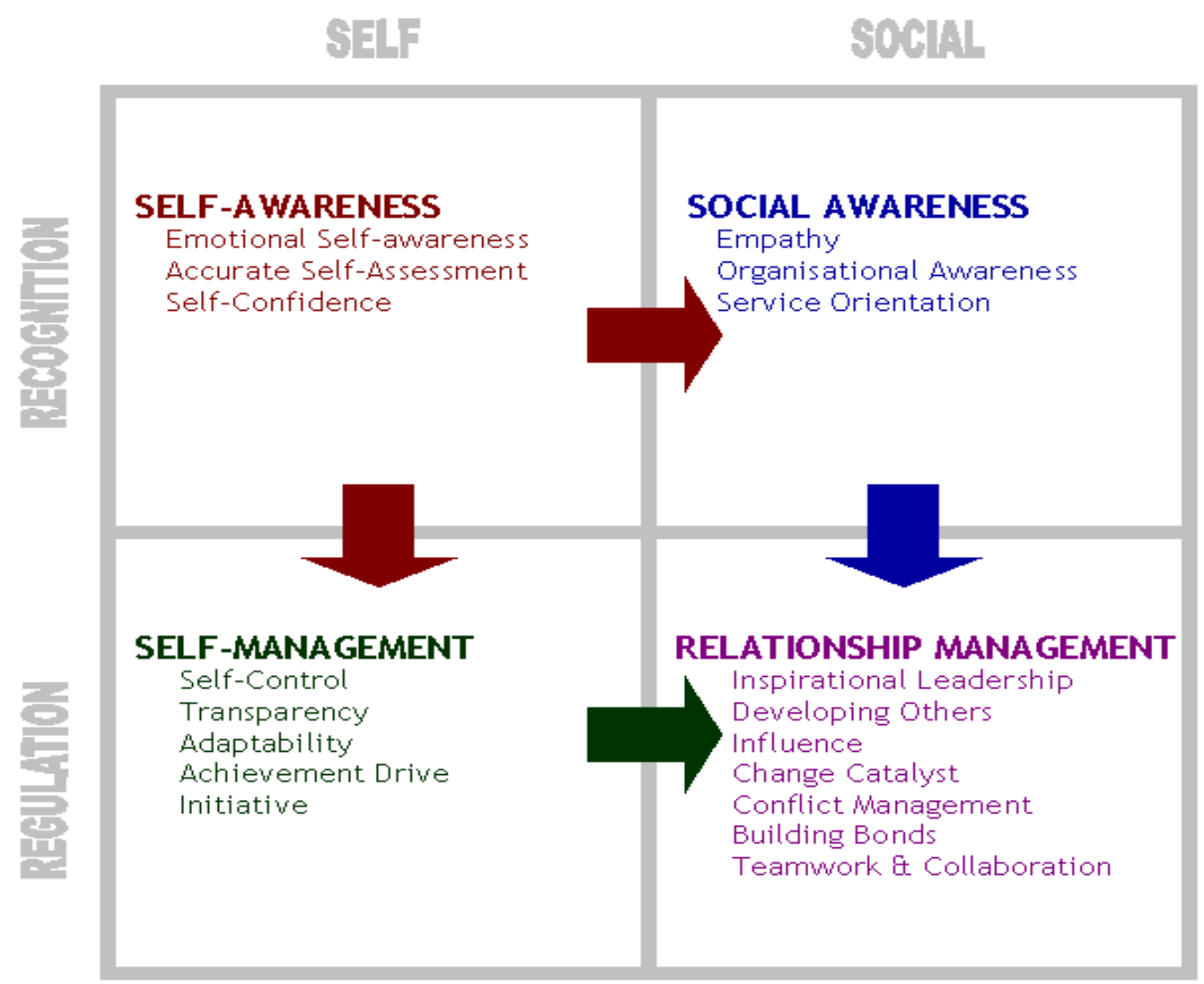

Figure 10. Daniel Goleman Emotional Intelligence Framework

Source: https://web.sonoma.edu/ 


\section{Total EIQ}

\section{Experiential ElQ}

Area

Scores
Recognizing emotions,

comparing them to

other sensations, and

determining how they

interact with thought
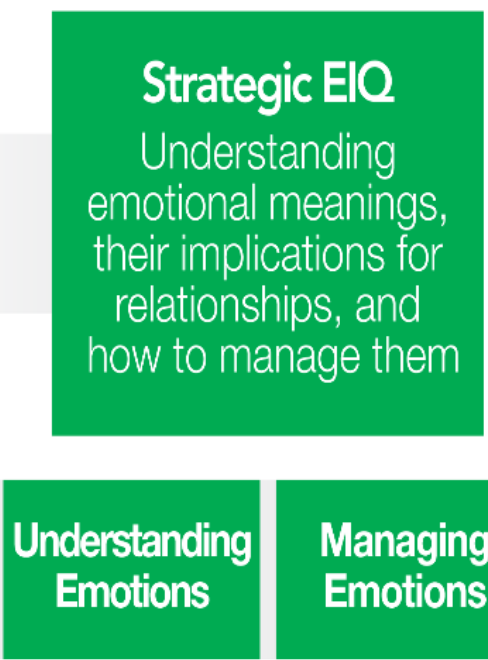

Managing

Emotions

Figure 11. MSCEIT, Mayer-Salovey-Caruso Emotional Intelligence Test.

Source: https://storefront.mhs.com/

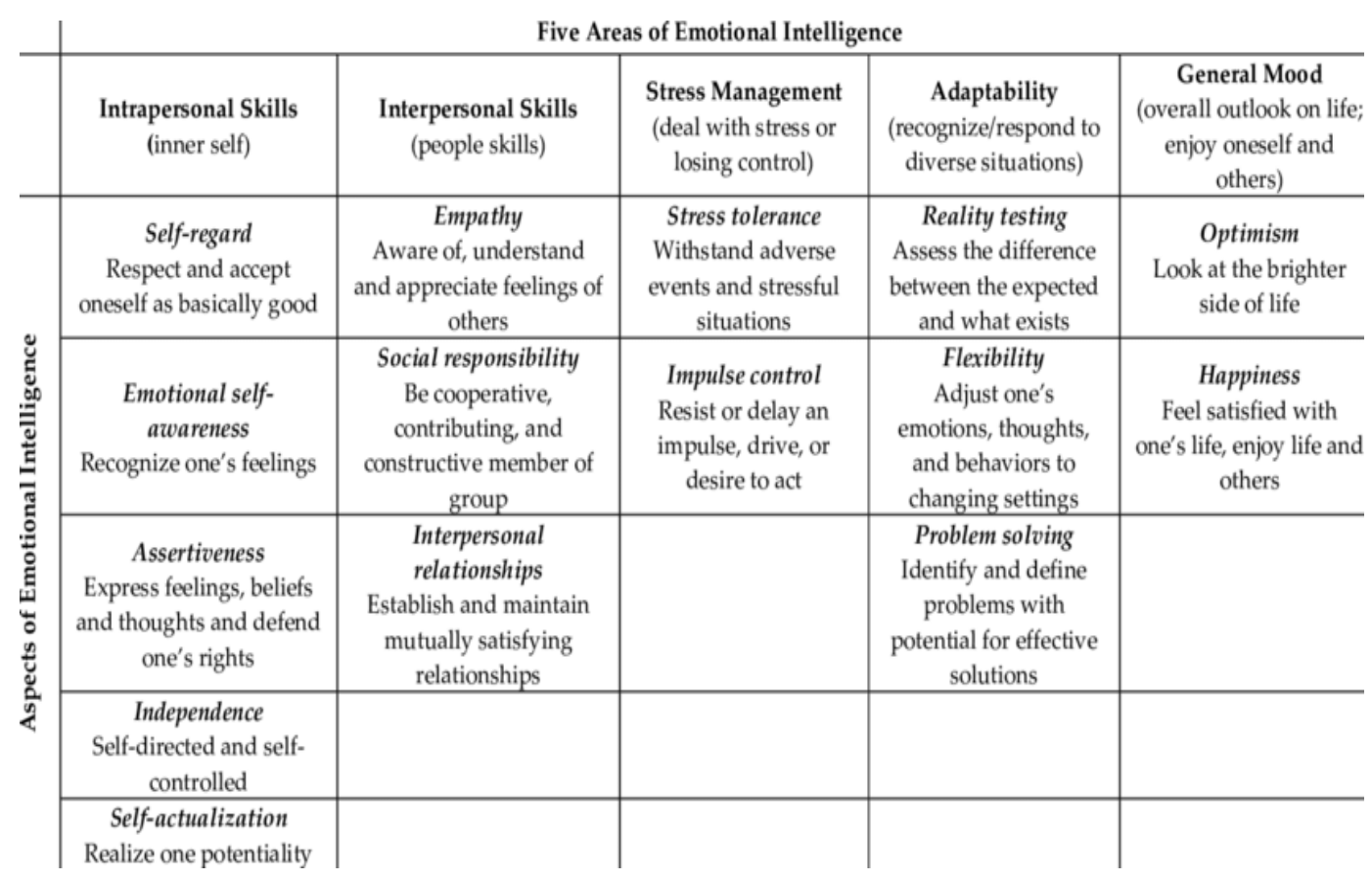

Figure 12. Bar-On Emotional Quotient Inventory (EQ-i)

Source: www.researchgate.net 